\title{
Group Investigation Technique on Indonesian High School Students' Writing Skill
}

\author{
${ }^{1}$ Raras Putri Andini, 2 Euis Yanah Mulyanah, ${ }^{3}$ Arjulayana \\ English department- Muhammadiyah University of Tangerang \\ Corresponding Email: raraspandini@gmail.com euis@umt.ac.id,arjulayana@umt.ac.ac.id
}

\begin{abstract}
Writing is the work of pouring ideas, expressing those ideas, and organizing them into statements and paragraphs that will be clear to a reader. Five points that students need to pay attention to in writing are content, organization, vocabulary, language use (grammar) and mechanic. Therefore, in this research, the researcher chooses Group Investigation Technique in teaching writing skill. The objective of this research is to discover whether any significant effect or not in the implementation of Group Investigation Technique on Indonesian high school students' writing skill because the students were not familiar with the written form in English in spite of, they have some assignments about that. Some students were not confident to write in English because they were afraid to make mistake in grammar. The researcher used Quantitative approach and Quasi Experiment method with Non-Equivalent Control Group Design. Both of experimental class and controlled class consist of 38 students as the sample of this research. The result of this research is shown the mean score of controlled class (X.FI.1) pretest $(58,5)$ is a little smaller than experimental class (X.FKK.2) pretest $(60,26)$. Meanwhile the mean score of controlled class posttest $(65,82)$ is way smaller than experimental class posttest $(73,4)$. Based on the data analysis posttest of hypotheses testing with significant level $5 \%(0,05)$, the result obtained that $\mathbf{t}_{\text {count }}(3,18)>\mathbf{t}_{\text {table }}(1,99)$ where the statistical hypotheses of $\mathrm{H}_{0}$ was rejected and $\mathrm{H}_{1}$ was accepted. So, it can be concluded that there is significant effect in the implementation of Group Investigation Technique on Indonesian High School Students' Writing Skill.
\end{abstract}

Keywords: Teaching English, Writing Skill, Group Investigation Technique 
Globish (An English-Indonesian journal for English, Education and Culture)

Vol. 9 No.1 January 2020

P-ISSN: 2301-9913, E-ISSN: 2597-9132

DOI: http://dx.doi.org/10.31000/globish.v7i2

\section{Introduction}

Students' environment in Indonesia does not really support students to increase their writing skill because they don't have enough partners to exchange and give opinion about their writing. As students, they need the right path that can guide them to make a good writing and improve their writing skill so their creativity is also improving as well. Harmer (2004) stated that the students should pay attention both in what to write and also in how to write.

Improving writing skill needs time, needs a lot of practice and also needs the right method. For students who live in countries that still use English as an International language, there are some problems that they will face in writing. Some of students will find it is hard to write their ideas due to the lack of vocabularies. Some techniques can be used by teachers to make writing is easier for students. According to Slavin Slavin in Achmad et al (1995:2018) there are many techniques of cooperative learning, they are Students Teams Achievement Divisions (STAD), Teams Games Tournaments, and Group Investigation.

Slavin in Achmad et al (1995:2018) stated that Group Investigation is a successful and useful learning technique because it involves task specialization. It also allows a class to work actively and collaboratively in small groups, besides, it enables students to actively take role in determining their own learning goals and process. It is an organizational approach that really is appropriate to tenth grade students in high school because they are still in transition state, they need to learn in well-organized way.

\section{Theoretical Framework}

\subsection{Writing}

Higgens et,al. (2006, p.313) states "'The process of writing organization is partially a goal-directed thinking process"' Miller (2011). It shows how writing is not only about putting words or symbols into written form, it is also not only about how to write that would be pleasing for the readers, but it is about how the process that has to be done before the writing itself is done. Writing is one of productive skills in English, and Harmer (2004) argued that the process of productive skills can be heard and seen while they are performed and writing gives a permanent product in the form of written piece. Process of writing itself is often influenced by the limitation of genres and theme that are important to be presented in learning activities.

Writing can be said as one of the most difficult skills for students to learn and teachers to teach. Many aspects have to be noted in writing. Students should have enough understanding about how to create a piece of writing effectively, creatively, and grammatically accurate.

\subsection{Group Investigation Technique}

Group Investigation is designed to compare to all aspects of the students' abilities and experience related to the process of learning, not just to the cognitive or social domains. It provides educators with an approach to the conduct of teaching and learning in school that differs significantly from traditional instruction. (Sharan \& Sharan, 1992, pg. 1) 
Killen in Asyik and Putri (1995:2016) said that Group Investigation Technique (GIT) is one of the cooperative learning techniques which is focusing on students' participation and activities. Group Investigation Technique allows students to be directly involved in teaching and learning process, so they are not merely recipients in classroom.

\subsection{Stages of Group Investigation}

Sharan and Sharan (1992) mentioned that students' ability will be increasing through a series of stages in planning and carrying out the Group Investigation Technique.

1) Stage I: Class determines sub-topics and organizes into research groups. In this stage, teacher holds a role as a leader of exploratory discussions and also as facilitator of awareness about the interesting aspects of the general topic. Students scan source, generate purpose questions, and sort them into categories that will become subtopics. The students then join the group to study the subtopic of teacher's choice or theirs.

2) Stage II: Groups plan their investigation. Discuss about what they will study and how they will go about it. Students choose resources and arrange the study tasks among themselves. Teacher should help groups formulating their plan.

3) Stage III: Groups carry out the investigation. Teacher will help with study skill, to help maintain cooperative norms. The information that students already are gathered, organized and analyzed together. They create conclusion from their findings. Group members bring their work in progress to exchange ideas and information then expand, clarify, and integrate them.

4) Stage IV: Groups prepare their presentations. Students determine the main idea of their findings then plan how to transmit it to the class. Group representatives coordinate plans for presenting their final work to class.

5) Stages V: Groups make their presentations. Teacher coordinates presentation and conducts discussion of feedback. Presentations are made in a variety of forms to the class. The audience take notes of the clarity and appeals of each presentation.

6) Stage VI: Together, teacher and students evaluate the final projects individually, in group, and class wide. Students share feedback about their investigations and about their affective experiences. Evaluation includes assessment of higher-level thinking process.

\section{Methodology}

The researcher conducted this research at SMKN 9 Tangerang from January 2019 until September 2019. In this research, researcher used quantitative approach with nonequivalent control group design. The population in this research was the tenth-grade students of SMKN 9 Tangerang in academic year 2018/2019 which was consisted of ten classes with total population 298 students. From the population mentioned before, based on Isaac and Michael (1981), the samples needed are 76 students with significant level 10\% (Riadi, 2014, p.21). So, the researcher took two classes consisting of 38 students in each 
P-ISSN: 2301-9913, E-ISSN: 2597-9132

DOI: http://dx.doi.org/10.31000/globish.v7i2

class with total samples are 76 students that represent the population.

Table Error! Use the Home tab to apply 0 to the text that you want to appear here.1 Sample of The Research

\begin{tabular}{c|c|c} 
& Classes & Total \\
\hline Controlled Class & X FI 1 & 38 \\
\hline Experimental Class & X FKK 2 & 38 \\
\hline Total & & $\mathbf{7 6}$
\end{tabular}

\section{Findings \& Discussion}

The research will show the data consists of pre-test and post-test result of experimental class and controlled class.

1.4. Controlled Class Pretest

Table 4.1 The Result of Controlled Class Pretest

\begin{tabular}{l|l|c} 
No. & \multicolumn{1}{|c|}{ Result of Data } & Pretest Score \\
\hline 1. & The lowest score & 40 \\
\hline 2. & The highest score & 80 \\
\hline 3. & Mean & 58,5 \\
\hline 4. & Median & 59,5 \\
\hline 5. & Mode & 60,1 \\
\hline 6. & Standard deviation & 11,18 \\
\hline 7. & Variance & 125,08
\end{tabular}

From the table above, it can be explained the result of controlled class pretest consists of the lowest score is 40 meanwhile the highest score is 80 , mean is $(58,5)$, median is $(59,5)$, mode is $(60,1)$, standard deviation is $(11,18)$, and variance score is $(125,08)$.

1.5. Controlled Class Post-test

Table 4.2 The Result of Controlled Class Post-test

\begin{tabular}{c|c|c} 
No. & Result of Data & Post-test Score \\
\hline 1. & The lowest score & 50
\end{tabular}

Group Investigation Technique on Indonesian High School Students' Writing Skill

${ }^{1}$ Raras Putri Andini, ${ }^{2}$ Euis Yanah Mulyanah, ${ }^{3}$ Arjulayana 


\begin{tabular}{c|c|c}
2. & The highest score & 84 \\
3. & Mean & 65,82 \\
\hline 4. & Median & 67,36 \\
\hline 5. & Mode & 71,77 \\
\hline 6. & Standard deviation & 9,19 \\
\hline 7. & Variance & 84,37
\end{tabular}

From the table above, it can be explained the result of controlled class post-test consists of the lowest score is 50 meanwhile the highest score is 84 , mean is $(65,82)$, median is $(67,36)$, mode is $(71,77)$, standard deviation is $(9,18)$, and variance score is $(84,37)$.

\subsection{Experimental Class Pretest}

Table 4.3 The Result of Experimental Class Pretest

\begin{tabular}{l|l|c} 
No. & Result of Data & Pre-test Score \\
\hline 1. & The lowest score & 37 \\
\hline 2. & The highest score & 80 \\
\hline 3. & Mean & 60,26 \\
\hline 4. & Median & 59,83 \\
\hline 5. & Mode & 54,7 \\
\hline 6. & Standard deviation & 11,37 \\
\hline 7. & Variance & 129,34
\end{tabular}

From the table above, it can be explained the result of experimental class pretest consists of the lowest score is 37 meanwhile the highest score is 80 , mean is $(60,26)$, median is $(59,83)$, mode is $(54,7)$, standard deviation is $(11,37)$, and variance score is $(129,34)$.

\subsection{Experimental Class Post-test}

Table 4.4 The Result of Experimental Class Post-test

\begin{tabular}{l|l|c} 
No. & Result of Data & Post-test Score \\
\hline 1. & The lowest score & 54 \\
\hline 2. & The highest score & 94
\end{tabular}

Group Investigation Technique on Indonesian High School Students' Writing Skill

${ }^{1}$ Raras Putri Andini, ${ }^{2}$ Euis Yanah Mulyanah, ${ }^{3}$ Arjulayana 
DOI: http://dx.doi.org/10.31000/globish.v7i2

\begin{tabular}{c|l|c}
3. & Mean & 73,4 \\
\hline 4. & Median & 71,5
\end{tabular}

\begin{tabular}{l|l|c} 
& Mode & 68.07 \\
\hline 6. & Standard deviation & 11,18 \\
\hline 7. & Variance & 124,97
\end{tabular}

From the table above, it can be explained the result of experimental class post-test consists of the lowest score is 54 meanwhile the highest score is 94 , mean is $(73,4)$, median is $(71,5)$, mode is $(68,07)$, standard deviation is $(11,18)$, and variance score is $(124,97)$.

\subsection{Data Normality Test}

To know whether the data in controlled and experimental class are normally distributed or not, the writer used chi square formula with " $5 \%$; k-1" to determine chi square table, $\mathrm{k}$ means the total number of class, then $5 \%$ means the significance

If $X^{2}<X^{2}$, the data are normally distributed. Meanwhile, if $X^{2}$

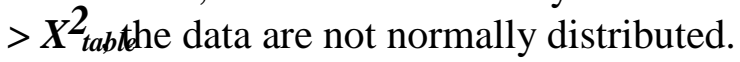

Table 4.5 The Result of Pretest and Post-test Normality Test

\begin{tabular}{l|l|c|c|c}
\multicolumn{2}{c|}{ Class } & $X_{\text {coun }}$ & $X_{\text {tabl }}^{2}$ & Result \\
\hline \multirow{2}{*}{ Controlled } & Pretest & 10,99 & 12,59 & Normal \\
\cline { 2 - 5 } & Post-test & 8,353 & 12,59 & Normal \\
\hline \multirow{2}{*}{ Experimental } & Pretest & 3,39 & 12,59 & Normal \\
\cline { 2 - 5 } & Post-test & 8,36 & 12,59 & Normal
\end{tabular}

Based on the result of controlled class pretest and post-test normality test above, the $\boldsymbol{X}^{\boldsymbol{2}_{\text {count }}}$ of pretest is 10,99. It means the $\boldsymbol{X}^{\boldsymbol{2}_{\text {count }}}$ is smaller than the $\boldsymbol{X}^{\mathbf{2} a b l e}$. Therefore,

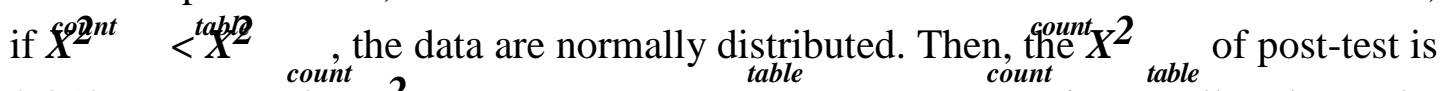
8,353. It means the $X^{2}$ $X^{2} \quad$. So, if $X^{2}<X^{2}$, the data are normally distributed.

For the experimental pretest and post-test normality test, it can be seen that the $\boldsymbol{X}_{\text {count }}^{\boldsymbol{2}}$

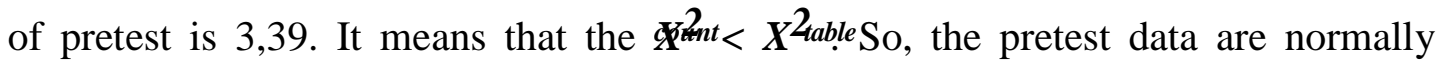
distributed. Meanwhile, the $X^{2}$ count of postest is 8,36 . It means that the $X^{\operatorname{cou} 2}<^{\operatorname{tal} X^{2} 2}$ . So, the postest data are also normally distributed. 


\subsection{Data Homogeneity Test}

In this study, the writer uses Fisher assumption for homogeneity test in significant level 5\% $(0,05)$ with the samples are 34 students from both controlled class and experimental class. The following criteria, if Fcount $<$ Ftable is accepted (homogenous) meanwhile if Fcount > Ftable is rejected (not homogenous).

Table 4.6 The Result of Pretest and Post-test Homogeneity Test

\begin{tabular}{l|l|l|c|c|c}
\multirow{2}{*}{ Data } & \multicolumn{2}{|c|}{ Class } & \multirow{2}{*}{ Fcount } & Ftable & Result \\
\cline { 2 - 3 } & Controlled & Experimental & & \\
\hline Pretest & 125,08 & 129,34 & 1,03 & 1,73 & Homogenous \\
\hline Postest & 84,37 & 124,97 & 1,48 & 1,73 & Homogenous
\end{tabular}

Based on the table above, the Fcount of pretest data homogeneity test is 1,03 and the Ftable is 1,73. According to the criteria, if Fcount $<$ Ftable, so the data are homogenous. Meanwhile, the Fcount of postest data homogeneity test is 1,48 and the Ftable is 1,73. According to the criteria, if Fcount $<$ Ftable, so the data are homogenous.

\subsection{Hypothesis Test}

Based on the result of normality and homogeneity test, the data are normally distributed and also homogenous. The researcher continued the calculation non parametric statistic using T-Test formulation to find out the significant effect from the research. The number of students in each class is 38 , it means $\mathrm{n} 1=\mathrm{n} 2$ so the test hypothesis used T-test formula for Separated Variance. In the test on pre-test class, the hypothesis as follows:

H0: There is no significant difference in students' writing skill between controlled class and experimental class.

$\mathrm{H}_{1}$ : There is significant difference in students' writing skill between controlled class and experimental class.

By using significant level 5\% $(0,05)$, the criteria is as follow:

Accepted $\mathrm{H}_{0}$ if $\mathrm{t}_{\text {count }}<\mathrm{t}$ table

Rejected $\mathrm{H}_{0}$ if $\mathrm{t}_{\text {count }}>\mathrm{t}_{\text {table }}$

From the calculation, the following data:

Table 4.7 T-test of Pre-Test in Controlled and Experimental Class

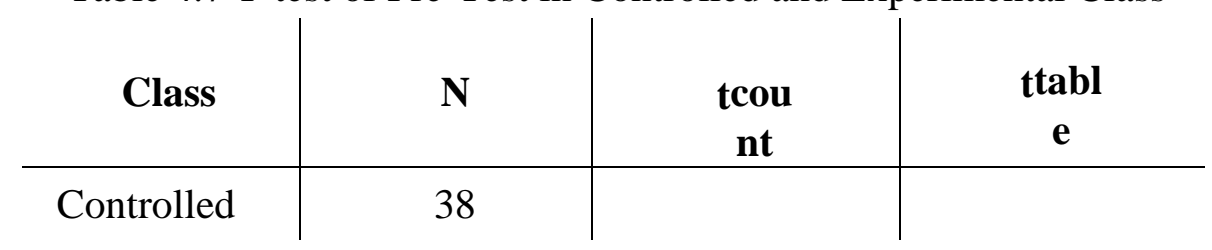

Group Investigation Technique on Indonesian High School Students' Writing Skill

${ }^{1}$ Raras Putri Andini, ${ }^{2}$ Euis Yanah Mulyanah, ${ }^{3}$ Arjulayana 


$$
\begin{array}{l|l|l|l}
\text { Experimental } & 38 & 0,67 & 1,99
\end{array}
$$

Based on the table above, the $t_{\text {count }}$ is 0,67 and $t_{\text {table }}$ is 1,99 . So, $t_{\text {count }}$ is smaller than $t_{\text {table }}$. The result shows that $\mathrm{H} 0$ is accepted and $\mathrm{H} 1$ is rejected. That means there is no significant difference in students' writing skill between controlled class and experimental class for pre-test.

Table 4.8 T-test of Post-Test in Controlled and Experimental Class

\begin{tabular}{c|c|c|c} 
Class & $\mathbf{N}$ & $\begin{array}{c}\text { tcou } \\
\mathbf{n t}\end{array}$ & $\begin{array}{c}\text { ttabl } \\
\mathbf{e}\end{array}$ \\
\hline Controlled & 38 & 3,18 & 1,99
\end{tabular}

Based on the table above, the $t_{\text {count }}$ is 3,18 and $t_{\text {table }}$ is 1,99 . So, $t_{\text {count }}$ is bigger than $t_{\text {table }}$. The result shows that $\mathrm{H} 0$ is rejected and $\mathrm{H} 1$ is accepted. Actually, there is an increase from the pretest to the post-test but after the calculation. It means that there is significant difference in students' writing skill between controlled class and experimental class after the researcher gave the treatment.

\subsection{Discussion}

Based on the hypotheses testing on pretest and post-test, it is shown that there is significant difference in students' writing skill between controlled class and experimental class. The first testing hypothesis of pre-test it shows that $\mathrm{H}_{0}$ is accepted. It can be known by statistical calculation student's pre-test score in controlled and experimental class. The calculation result shows the $t_{\text {count }}$ is 0.67 and the $t_{\text {table }}$ is 1.99 it can be concluded that there is no significant different of controlled and experimental class.

The second testing hypothesis of post-test shows that $\mathrm{t}_{\text {count }}$ of post-test is 3,18 and $\mathrm{t}_{\text {table }}$ is 1,99 . So, the statistical hypotheses of $\mathrm{H}_{0}$ is rejected and $\mathrm{H}_{1}$ is accepted. In fact, there is difference score before and after the writer gave treatment in experimental class. It is shown that the mean of experimental class in pretest and post-test is 60,26 to 73,4 .

The use of Group Investigation Technique can improve student's writing skill. So, it is effective to use Group Investigation Technique to improve student's writing skill. The technique also gives the students more interest in exploring writing because they can freely to discuss and share about recount text with their friends. Students showed their enthusiasm by actively participating in teaching and learning process.

\section{Conclusion}

Based on the result of presentation of data analysis and hypotheses testing, it can be concluded that there is significant effect using Group Investigation Technique on the tenthgrade student's writing skill. The writer using pretest and post-test in essay form to collect the data. Group Investigation Technique is one technique that can help students to improve

Group Investigation Technique on Indonesian High School Students' Writing Skill 
their writing skill. It can be proven by statistical calculation in testing hypothesis, the result shows significant student's score in writing. Student's score in experimental class which had been given treatment have better than student's score in controlled class.

\section{REFERENCES}

Achmad et al. (2018). Application of Group Investigation (GI) Learning Model in Pendidikan IPS SD Course, To Improve Students' Critical Thinking Skills At Pgsd Universitas Negeri Makassar. IOSR Journal of Research \& Method in Education (IOSR-JRME), 42-43.

Asyik \& Putri. (2016). Using The Group Investigation Technique in Teaching Reading Comprehension. ENGLISH EDUCATION JOURNAL (EEJ), 1-15.

Brown \& Dowling. (1998). Doing Research/Reading Research: A mode of Interrogation for Education. London: The Falmer Press.

Brown, H. (2004). Language Assessment Principle and Classroom Pratices. Longman.

Chrystal, D. (2003). English As Global Language. New York: Cambridge University Press.

Efendi, Y. (2017). The Influence of Using Small Group Discussion Towards Students' Descriptive Text Writing Ability at The First Semester of The Tenth Grade of SMA Hidayatul Muslihin Way Kanan in The Academic Year of 2016/2017. Lampung: State Islamic University Raden Intan.

Harmer, J. (2004). How to Teach Writing. Harlow: Longman.

Iswardati. (2016). The Implementation of Group Investigation to Improve the Students' Speaking Skill. Dinamika Ilmu, 245-261.

Johnson. (1987). Approaches to Research in Second Language Learning. London: Longman Group Ltd.

Lodico et al. (2006). Methods In Educational Research From Theory To Practice. San Fransisco: Jossey-Bass.

Nunan, D. (2003). PRACTICAL ENGLISH LANGUAGE TEACHING. Singapore: Mc Graw Hill.

Oshima, A., \& Hogue, A. (2006). Writing Academic English (4th ed). USA: Pearson Longman.

Riadi, D. (2014). Metode Statistika Parametrik \& Nonparametrik. Tangerang: PT Pustaka Mandiri.

Rohim, A. (2017). Essay Writing: How To Write An Essay. Yogyakarta: Penerbit Deepublish (CV BUDI UTAMA).

Sharan, \& Sharan. (1992). Expanding cooperative learning through group investigation. New York: Teachers College Press.

Stephanie A.Miller. (2011) Journal Using Graphic Organizers To Increase Writing Performance. (230-235)

Sugiono. (2010). Metode Penelitian Pendidikan. Alfabeta:Bandung

Sugiyono. (2010). Statistika Untuk Penelitian. Bandung: Alfabeta.

Weigle S.C. (2009). Assessing Writing. Cambridge University Press 